\title{
Iron oxide nanoparticles induce reversible endothelial-to-mesenchymal transition in vascular endothelial cells at acutely non-cytotoxic concentrations
}

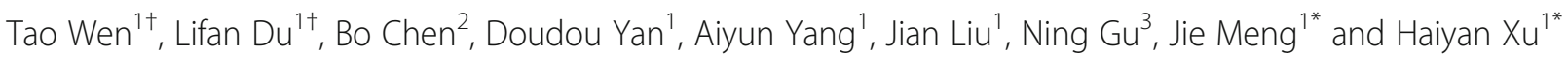

\begin{abstract}
Background: Iron oxide nanoparticles (IONPs) have been extensively studied in different biomedical fields. Recently, the non-cytotoxic concentration of IONPs induced cell-specific response raised concern of their safety. Endothelial cell exposure was unavoidable in their applications, while whether IONPs affect the phenotype of vascular endothelial cells is largely unknown. In this work, the effect of IONPs on endothelial-to-mesenchymal transition (EndMT) was investigated in vitro and in vivo.

Results: The incubation with $\gamma-\mathrm{Fe}_{2} \mathrm{O}_{3}$ nanoparticles modified with polyglucose sorbitol carboxymethyether (PSC-Fe $\mathrm{O}_{3}$ ) at non-cytotoxic concentration induced morphological changes of human umbilical vein endothelial cells (HUVECs) from cobblestone-like to spindle mesenchymal-like morphology, while PSC-Fe $\mathrm{O}_{3}$ mostly stay in the culture medium and intercellular space. At the same time, the endothelial marker CD31 and VE-cadherin was decreased along with the inhibitory of angiogenesis properties of HUVEC. Meanwhile, the mesenchymal marker a-smooth muscle actin (a-SMA) and fibroblast specific protein (FSP) was up regulated significantly, and the migration ability of the cells was enhanced. When ROS scavenger mannitol or AA was supplemented, the EndMT was rescued. Results from the in vivo study showed that, expression of CD31 was decreased and a-SMA increased in the liver, spleen and kidney of mice given $\mathrm{PSC}-\mathrm{Fe}_{2} \mathrm{O}_{3}$, and the density of collagen fibers in the liver sinusoid of mice was increased. The supplementary mannitol or AA could reverse the degree of EndMT in the tissues. Mechanistic study in vitro indicated that the level of extracellular hydroxyl radicals ( $(\mathrm{OH})$ was up regulated significantly by $\mathrm{PSC}-\mathrm{Fe}_{2} \mathrm{O}_{3}$, which induced the response of intracellular ROS and resulted in the EndMT effect on HUVECs.
\end{abstract}

Conclusion: The PSC-Fe $\mathrm{O}_{3}$ was capable of inducing EndMT in the endothelial cells at acutely non-cytotoxic dose due to its intrinsic peroxidase-like activity, though they were few taken up by endothelial cell. The EndMT effect on HUVEC can be rescued by ROS scavenger in vitro and in vivo.

Keywords: Iron oxide nanoparticle, Endothelial-to-mesenchymal transition, Reactive oxygen species, Reversible

\section{Background}

Iron oxide nanoparticles (IONPs) have been intensively investigated and developed in many biomedical fields, such as intravenous cell targeting, labeling and separation, magnetic resonance imaging contrast, drug or gene delivery system, and hyperthermia [1-3], because they show a low

\footnotetext{
* Correspondence: mengjie@ibms.pumc.edu.cn; xuhy@pumc.edu.cn

${ }^{\dagger}$ Tao Wen and Lifan Du contributed equally to this work.

'Institute of Basic Medical Sciences, Chinese Academy of Medical Sciences \&

Peking Union Medical College, Beijing 100005, China

Full list of author information is available at the end of the article
}

cytotoxicity in a quite large range of tested concentration $[4,5]$. Nevertheless, potential effects of IONPs at noncytotoxic concentrations on human health have been explored in recent years, especially on vascular endothelial cells, because blood vessel is one of the major barriers for INOPs intended to use as therapeutics and diagnostics. For examples, it was reported that IONPs exposure induced the elongated morphology and increased elastic modulus of endothelial cells [6,7]. Even no cytotoxicity was detected, at low amount of IONPs, the endocrine and urea

(c) The Author(s). 2019 Open Access This article is distributed under the terms of the Creative Commons Attribution 4.0 International License (http://creativecommons.org/licenses/by/4.0/), which permits unrestricted use, distribution, and 
transporter function, inflammatory responses, angiogenesis function of endothelial cells (ECs) were found to change [8]. The endothelial integrity was also reported to alter via interplay with barrier function and attenuation of cytoprotective and anti-inflammatory $\mathrm{NO}$ production at noncytotoxic concentration of IONPs [9]. These cues imply possible effects of IONPs at non-cytotoxic concentration on the phenotype of ECs.

Endothelium to mesenchymal transition (EndMT) is one changed phenotype of endothelial cells that represents losing endothelial characteristics and gaining a mesenchymal phenotype [10], which have a significant role in some diseases, especially fibrosis in liver [11, 12], kidney [13], cardiac [14], and atherosclerosis [15], diabetes [16] and cancer [17]. It also has been documented that endothelial cells can undergo EndMT in certain physiological environmental stimulations including growth factor TGF $\beta$ [18], materials stiffness [19], and stretching stress [20]. Whether IONPs can induce EndMT is unknown and worthy to note.

In this work, whether $\gamma-\mathrm{Fe}_{2} \mathrm{O}_{3}$ nanoparticles modified with polyglucose sorbitol carboxymethyether (PSC$\mathrm{Fe}_{2} \mathrm{O}_{3}$ ) were able to inducing EndMT upon human umbilical vein endothelial cells (HUVECs) was investigated in vitro and in vivo. We showed that $\mathrm{PSC}-\mathrm{Fe}_{2} \mathrm{O}_{3}$ at acutely non-cytotoxic concentration significantly reduced the expression of endothelial marker CD31 and VE-cadherin, meanwhile increased the mesenchymal marker $\alpha$-smooth muscle actin ( $\alpha$-SMA) and fibroblast specific protein (FSP) due to the peroxidase-like activity, by which the migration of endothelial cells was enhanced and their angiogenic function was inhibited, clearly indicating the occurrence of EndMT in the endothelial cells. The underlying mechanism of $\mathrm{PSC}-\mathrm{Fe}_{2} \mathrm{O}_{3}$ induced EndMT was also elucidated.

\section{Results}

\section{Characterization and cytotoxicity of PSC- $-\mathrm{Fe}_{2} \mathrm{O}_{3}$}

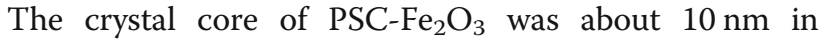
diameter (Fig. 1a), and the average hydrodynamic diameter was $58 \mathrm{~nm}$ with $-30 \mathrm{mV}$ of zeta potential. It should be noted that $\mathrm{PSC}-\mathrm{Fe}_{2} \mathrm{O}_{3}$ did not show any cytotoxicity to HUVECs when its concentration was reached at $600 \mu \mathrm{g} / \mathrm{mL}$ (Fig. 1b), however, the morphology of the cells changed significantly, showing a spindle mesenchymal-like morphology at the concentration while losing their endothelial characteristic polygonal shape (Fig. 1c). The ratio of length to diameter (L/D) for the endothelial cells was two folds of that of control group when incubated with $600 \mu \mathrm{g} / \mathrm{mL}$ PSC- $\mathrm{Fe}_{2} \mathrm{O}_{3}$ (Fig. 1d). When observed at a lower confluence of $70 \%$ after $\mathrm{PSC}-\mathrm{Fe}_{2} \mathrm{O}_{3}$ treatment, HUVECs also became spindle mesenchymallike morphology (Additional file 1: Figure S1).

\section{PSC- $\mathrm{Fe}_{2} \mathrm{O}_{3}$ induce EndMT}

Next we investigated what happened on the phenotype of HUVECs when their morphology changed largely. The expression of CD31 and VE-cadherin (VE-cad) was examined by immunoblotting and immunofluorescence upon HUVECs incubated with $\mathrm{PSC}-\mathrm{Fe}_{2} \mathrm{O}_{3}$ at different concentrations. It was shown that the level of VE-cad was down regulated when $\mathrm{PSC}-\mathrm{Fe}_{2} \mathrm{O}_{3}$ was at $300 \mu \mathrm{g} / \mathrm{mL}$ or $600 \mu \mathrm{g} / \mathrm{mL}$, and CD31 was decreased as well when PSC- $\mathrm{Fe}_{2} \mathrm{O}_{3}$ was reached $600 \mu \mathrm{g} / \mathrm{mL}$, while the expression of $\alpha$-SMA and FSP significantly increased in the tested concentrations (Fig. 2a, b). These results clearly indicated that PSC- $\mathrm{Fe}_{2} \mathrm{O}_{3}$ was capable of inducing endothelial cell transformation to mesenchymal cells (EndMT) process at the acutely non-cytotoxic concentration.

\section{PSC- $-\mathrm{Fe}_{2} \mathrm{O}_{3}$ mainly stayed in the culture medium and intercellular space}

To understand how EndMT was triggered by PSC$\mathrm{Fe}_{2} \mathrm{O}_{3}$, we first examined whether PSC- $\mathrm{Fe}_{2} \mathrm{O}_{3}$ were internalized by HUVECs. Results from Prussian blue Staining showed little blue color was observed in the cytoplasm of HUVEC incubated with PSC- $\mathrm{Fe}_{2} \mathrm{O}_{3}$, only sparkle of blue staining was seen between the cells when PSC$\mathrm{Fe}_{2} \mathrm{O}_{3}$ was at $600 \mu \mathrm{g} / \mathrm{mL}$ (Fig. 3a), suggesting few PSC$\mathrm{Fe}_{2} \mathrm{O}_{3}$ were internalized. With TEM, no appreciable PSC- $-\mathrm{Fe}_{2} \mathrm{O}_{3}$ was observed inside the cells; instead, a small part of PSC- $\mathrm{Fe}_{2} \mathrm{O}_{3}$ located in the intercellular space of the cells (Fig. 3b), and most of $\mathrm{PSC}-\mathrm{Fe}_{2} \mathrm{O}_{3}$ (more than 99\%) stayed in the culture medium, which was determined by phenanthroline spectrophotometric method. To further validate above observations, cell lysates were prepared by two procedures and the iron content of the lysates was determined by phenanthroline method (Fig. 3c). It was shown that as for the samples prepared by lysis only (procedure I), the iron content of $\mathrm{PSC}-\mathrm{Fe}_{2} \mathrm{O}_{3}$ groups was significantly higher than that of control group and concentration dependent. While for the samples prepared by the lysis following trypsin digestion (procedure II), no difference of iron content was observed between the control group and the two $\mathrm{PSC}-\mathrm{Fe}_{2} \mathrm{O}_{3}$ groups (Fig. 3d). Because the trypsin digestion made the cells disconnected, therefore the increased iron content in lysates of procedure I was attributable to the $\mathrm{PSC}-\mathrm{Fe}_{2} \mathrm{O}_{3}$ locating in the intercellular space. At the same time, the results provided further evidence of few $\mathrm{PSC}-\mathrm{Fe}_{2} \mathrm{O}_{3}$ were taken up.

\section{Extracellularly PSC- $-\mathrm{Fe}_{2} \mathrm{O}_{3}$ induced ROS increase by peroxidase-like activities}

Internalized nanoparticles usually up-regulate intracellular $\mathrm{ROS}[21,22]$. Although $\mathrm{PSC}-\mathrm{Fe}_{2} \mathrm{O}_{3}$ mainly located in the culture medium and intercellular space instead of being taken up by endothelial cells, the impact of PSC- 


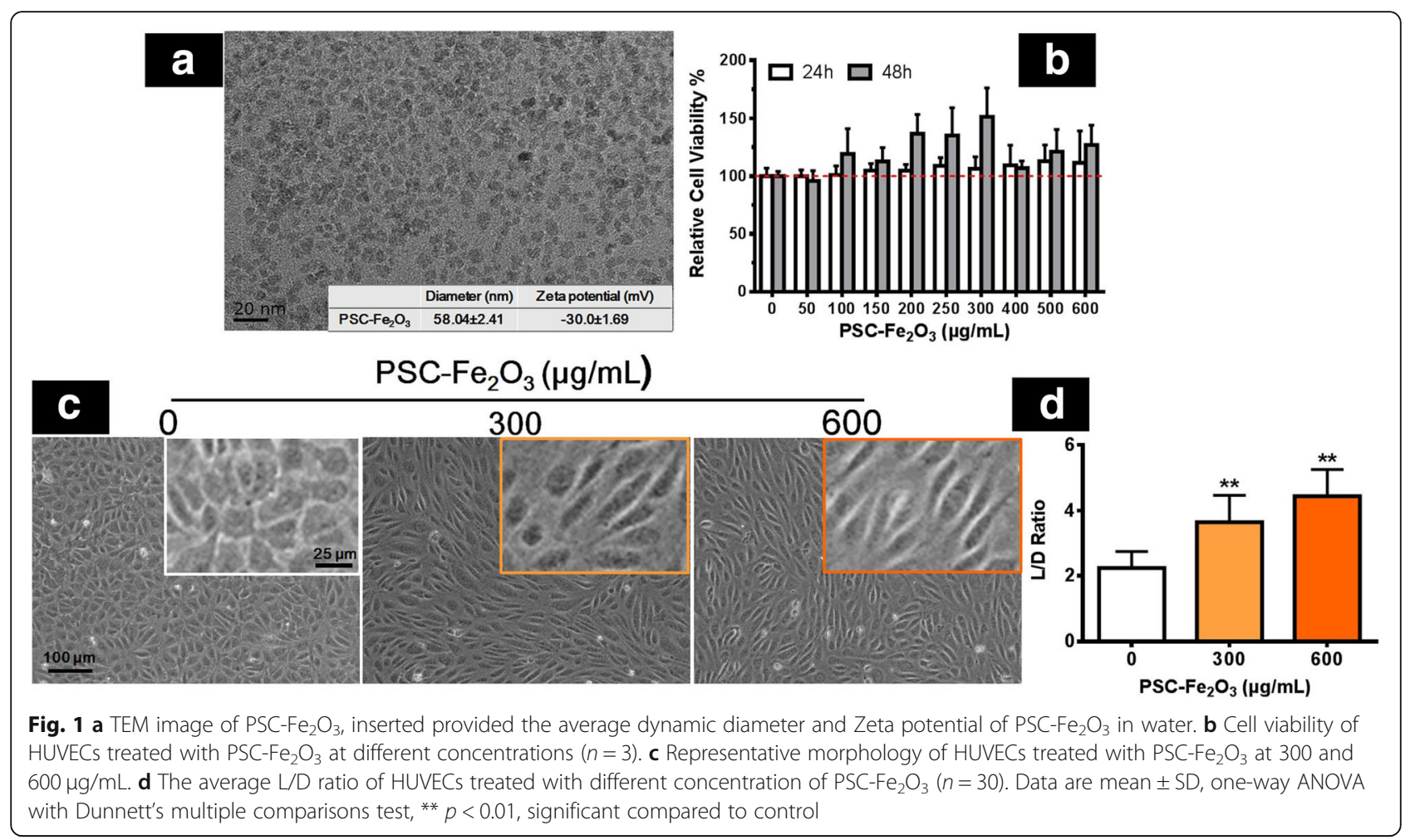

$\mathrm{Fe}_{2} \mathrm{O}_{3}$ on the intracellular ROS was also examined. It was striking that the intracellular ROS of HUVECs was increased when incubated with PSC- $\mathrm{Fe}_{2} \mathrm{O}_{3}$, and the effect was in concentration dependent manner (Fig. 4a). We also examined the change of ROS stress marker HO- 1 at gene level. Results showed that the expression of $\mathrm{HO}-1$ was increased in dose-dependent manner when HUVECs were exposed with PSC- $\mathrm{Fe}_{2} \mathrm{O}_{3}$ (Fig. 4b), which confirmed that ROS played a key role in $\mathrm{PSC}-\mathrm{Fe}_{2} \mathrm{O}_{3}$-induced EndMT. At the same time, the extracellular ROS was increased and $\mathrm{H}_{2} \mathrm{O}_{2}$ content decreased (Fig. 4b, c), which was concentration dependent too. It has been documented that IONPs is capable of decomposing $\mathrm{H}_{2} \mathrm{O}_{2}$ into hydroxyl radicals (.OH) due to its peroxidaselike activity [23], we next accessed the peroxidase-like activity of PSC- $\mathrm{Fe}_{2} \mathrm{O}_{3}$ upon the commonly used peroxidase colorimetric substrates o-phenylenediamine (OPD) in the presence of $\mathrm{H}_{2} \mathrm{O}_{2}$ [24]. As Fig. 4d proved, PSC$\mathrm{Fe}_{2} \mathrm{O}_{3}$ catalyzed $\mathrm{H}_{2} \mathrm{O}_{2}$ into $\cdot \mathrm{OH}$ in a concentration dependent manner, showing the peroxidase property. Furthermore, we detected $\cdot \mathrm{OH}$ directly by electron spin resonance (ESR) spectroscopy with the help of a spin trap 5, 5-Dimethyl-1-pyrroline N-oxide (DMPO). The ESR spectrum of the spin adduct DMPO/.OH showed four lines with relative intensities of 1:2:2:1 and hyperfine splitting parameters of $a_{N}=13.56, a_{H}^{\beta}=12.30$, and $a_{H}^{\gamma}=0.66$ [25] (Fig. 4f), which provided evidence that there was increased $\cdot \mathrm{OH}$ in the extracellular environment. Taken together above, we demonstrated that extracellular PSC$\mathrm{Fe}_{2} \mathrm{O}_{3}$ decomposed $\mathrm{H}_{2} \mathrm{O}_{2}$, which resulted in the production of extracellular $\mathrm{OH}$ that induced up-regulation of intracellular ROS.

\section{ROS scavengers reverse EndMT of HUVEC}

Some reports suggested that the up-regulation of intracellular ROS was one crucial factor inducing EndMT $[26,27]$, therefore we next investigated the relationship between the EndMT and IONP-induced ROS. It was shown that the supplement of hydroxyl radicals $(\cdot \mathrm{OH})$ scavenger mannitol [28] or non-specific ROS scavenger ascorbic acid (AA) [29] was capable of reducing the intracellular ROS level of HUVECs incubated with PSC$\mathrm{Fe}_{2} \mathrm{O}_{3}$ (Fig. 5a). Moreover, either mannitol or AA was able to increase the expression of VE-Cad and CD31 while to decrease $\alpha$-SMA and FSP for HUVEC in the presence of $\mathrm{PSC}-\mathrm{Fe}_{2} \mathrm{O}_{3}$ (Fig. $5 \mathrm{~b}$ and c). Although the change was not large at each immunoblots, the CD31 was decreased by $\mathrm{PSC}-\mathrm{Fe}_{2} \mathrm{O}_{3}$ at $600 \mu \mathrm{g} / \mathrm{mL}$ with statistical significance (Additional file 1: Figure S2A and B). To confirm this in further, we conducted additional experiments to investigate the change of CD31 from gene level. It was shown that $\mathrm{CD} 31$ was down regulated in the present of $600 \mu \mathrm{g} / \mathrm{mL}$ PSC- $\mathrm{Fe}_{2} \mathrm{O}_{3}$ and could be rescued by adding AA (Additional file 1: Figure S2C). These results strongly suggested that $\mathrm{PSC}-\mathrm{Fe}_{2} \mathrm{O}_{3}$ induced extracellular $\cdot \mathrm{OH}$ was one crucial factor for the 

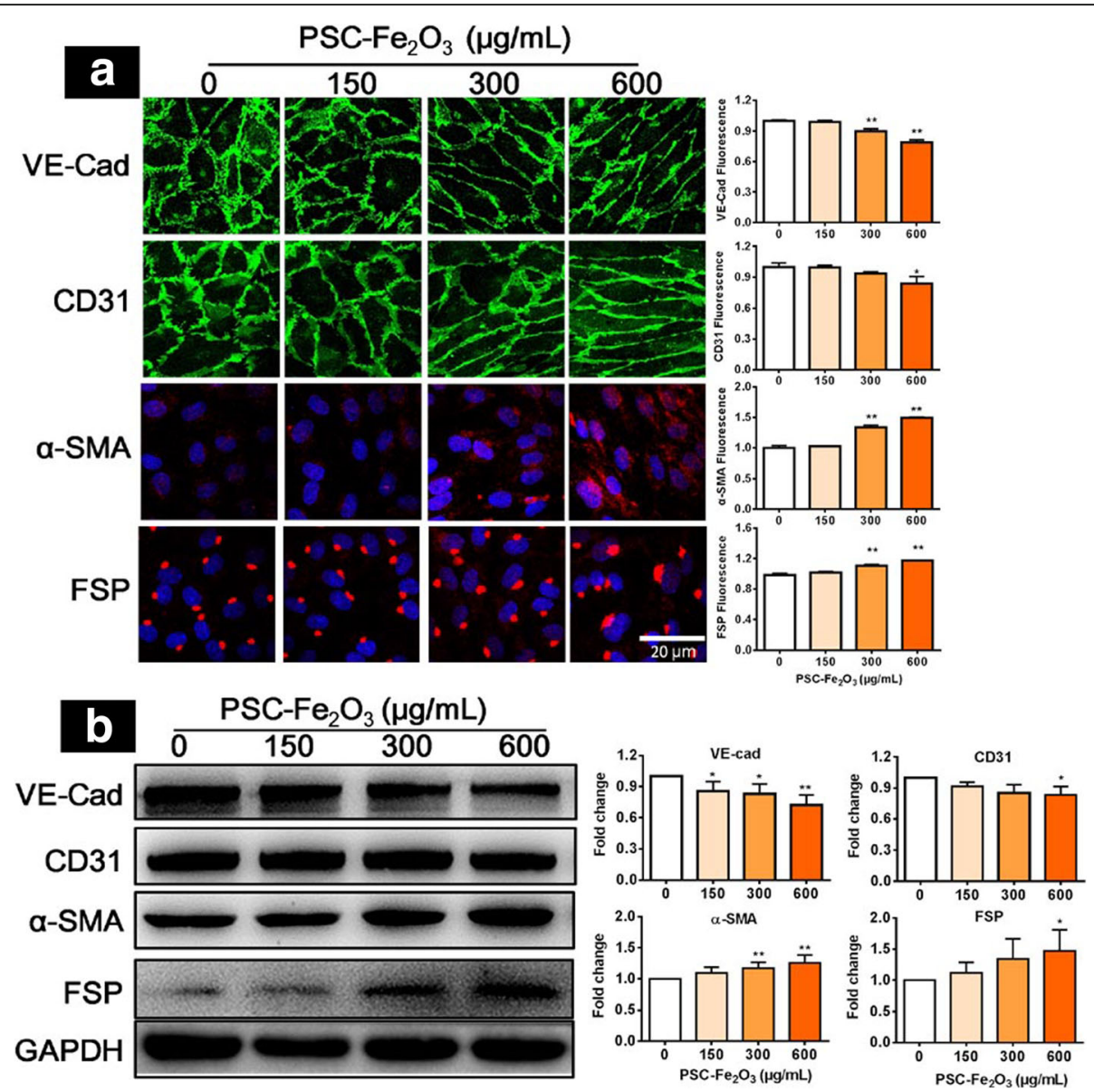

Fig. 2 PSC-Fe $\mathrm{O}_{3}$ at non-cytotoxic concentration induced EndMT in HUVECs. a Representative fluorescence confocal microphotographs and quantitative fluorescence intensity of HUVECs immunostatined with endothelial cell marker CD31 (green) or VE-cadherin (green) and mesenchymal marker a-SMA (red) or FSP (red), counterstained with DAPI for nuclei (blue). b Representative immunoblots and quantification of CD31, VE-cadherin, $a-S M A$, FSP of protein lysates from HUVECs treated with $\mathrm{PSC}-\mathrm{Fe}_{2} \mathrm{O}_{3}$. Data are mean $\pm S D, n=3$, one-way ANOVA with Dunnett's multiple comparisons test, ${ }^{*} p<0.05,{ }^{* *} p<0.01$, significant compared to control

occurrence of EndMT, which could be scavenged by the supplement of antioxidants.

As EndMT can inhibit the function of angiogenesis and promote invasion for endothelial cells [30, 31], we examined the ability of HUVECs to form vessel-like structures in the presence of $\mathrm{PSC}-\mathrm{Fe}_{2} \mathrm{O}_{3}$. The observation under microscope showed that the tubules formed by control HUVECs were dense, complete and continuous, while those formed by HUVECs incubated with PSC- $\mathrm{Fe}_{2} \mathrm{O}_{3}$ were less, only sparse network and few branches were observed. When supplemented with AA, the HUVECs incubated with $\mathrm{PSC}-\mathrm{Fe}_{2} \mathrm{O}_{3}$ recovered their angiogenic ability, evidenced by the increased tubule formation (Fig. 6a). Quantification results showed that the number of meshes was significantly different between control group and $\mathrm{PSC}-\mathrm{Fe}_{2} \mathrm{O}_{3}$ group, and between PSC$\mathrm{Fe}_{2} \mathrm{O}_{3}$ group and $\mathrm{PSC}-\mathrm{Fe}_{2} \mathrm{O}_{3}$ with AA group (Fig. 6b). At the same time, the covering rate of wound scratch was faster for PSC- $\mathrm{Fe}_{2} \mathrm{O}_{3}$ group than that for the control group, indicating the function of migration and invasion of the cells was enhanced, and which could also be reverted by adding AA (Fig. 6c, d).

\section{ROS scavengers rescued PSC- $\mathrm{Fe}_{2} \mathrm{O}_{3}$ induced EndMT in vivo}

The EndMT induced by PSC- $\mathrm{Fe}_{2} \mathrm{O}_{3}$ was further investigated in healthy $\mathrm{Balb} / \mathrm{c}$ mice. The mice were divided into four groups: control, $\mathrm{PSC}-\mathrm{Fe}_{2} \mathrm{O}_{3}$ alone, $\mathrm{PSC}-\mathrm{Fe}_{2} \mathrm{O}_{3}$ plus mannitol intravenously, and $\mathrm{PSC}-\mathrm{Fe}_{2} \mathrm{O}_{3}$ intravenously plus AA oral administration. The exposure dose and routine were chosen according to the results in vitro and the references $[4,32]$. Results obtained from the immunofluorescence staining showed that the expression of CD31 was decreased and $\alpha$-SMA increased in the liver, kidney and spleen of mice given $\mathrm{PSC}-\mathrm{Fe}_{2} \mathrm{O}_{3}$ alone, while the addition of mannitol or AA rescued the level of the two markers, which clearly indicated that oxidative stress induced by $\mathrm{PSC}-\mathrm{Fe}_{2} \mathrm{O}_{3}$ could induce EndMT 


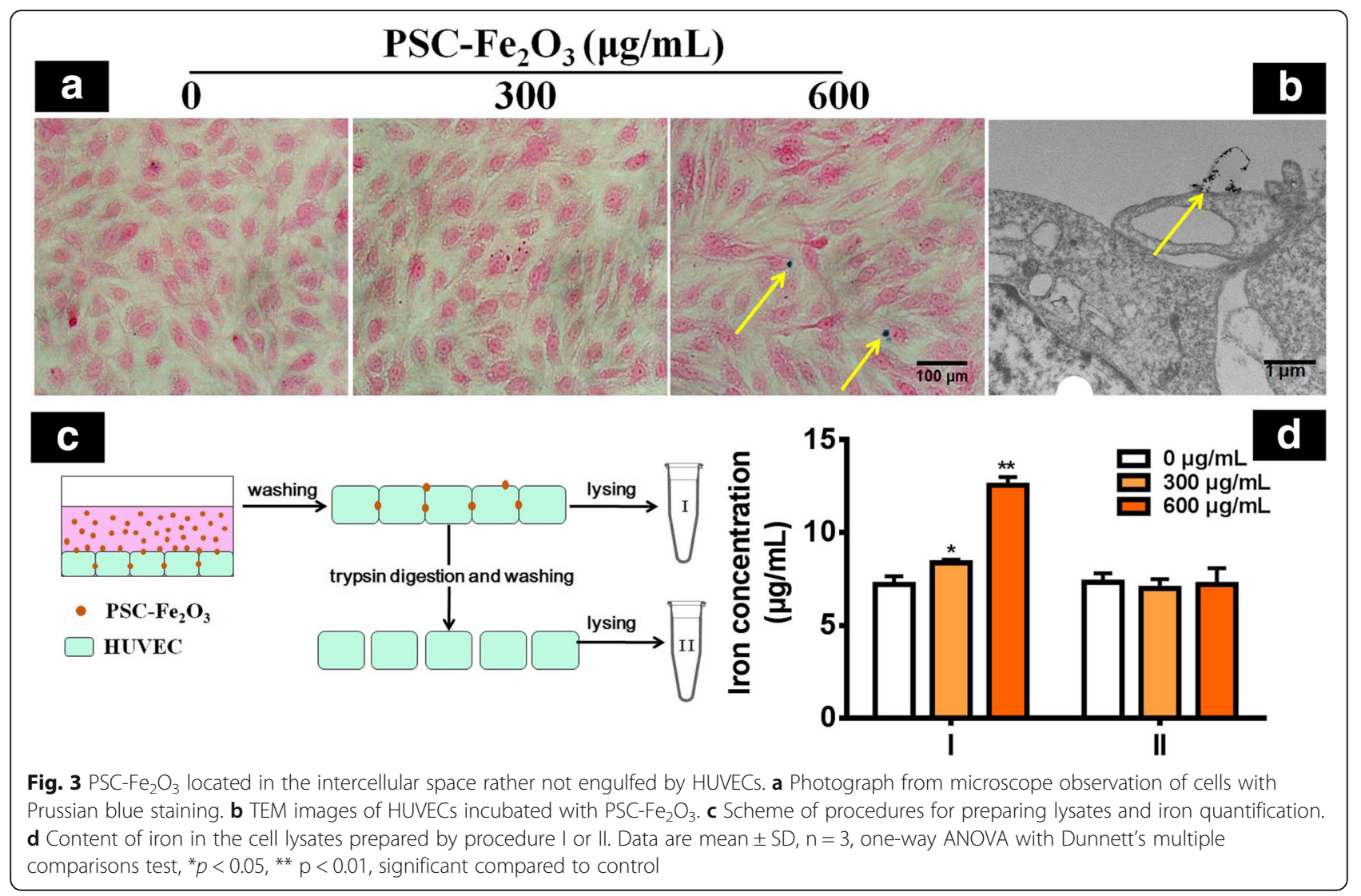

in those organs, and the effect was rescued by the use of ROS scavengers (Fig. 7). The immunohistochemical staining with the liver tissue also provided side evidence of down regulation for CD31 and upregulation for $\alpha$ SMA (Additional file 1: Figure S3), which was consistent with the result of immunofluorescence staining. As shown in previous reports, either human microvascular endothelial cell (HMVEC) or liver sinusoidal endothelial cells (LSEC) underwent leakiness through the disruption of VE-cad when exposed to titanium dioxide nanoparticles [33, 34], which suggested endothelial cells from different sources have some features in common.

In addition, results from Masson's trichrome staining showed that the density of collagen fibers in the liver sinusoid of mice administrated with $\mathrm{PSC}-\mathrm{Fe}_{2} \mathrm{O}_{3}$ alone was increased, which indicated the occurrence of liver fibrosis. The supplements of mannitol or AA could reduce the density of collagen fibers (Fig. 8).

\section{Discussion}

Endothelial-to-mesenchymal transition (EndMT) is accompanied with a progressive loss of endothelial markers and cell-to-cell adhesion, transition towards a mesenchymal phenotype, and enhancement on cell migration and invasion, which has been recognized to play a diverse role in many diseases, such as fibrosis, systemic sclerosis, diabetes and malignancy [10]. In this work, we revealed that PSC- $-\mathrm{Fe}_{2} \mathrm{O}_{3}$ could induce EndMT at acutely non-cytotoxic concentration. In order to figure out whether the occurrence of EndMT came from the modification of PSC, we also performed experiments with bare $\mathrm{Fe}_{2} \mathrm{O}_{3}$ nanoparticles (bare- $\mathrm{Fe}_{2} \mathrm{O}_{3}$ ) of $10 \mathrm{~nm}$ in diameter (Additional file 1: Fig. S4A). The bare- $\mathrm{Fe}_{2} \mathrm{O}_{3}$ showed $50 \%$ of viability when the concentration was reached $300 \mu \mathrm{g} / \mathrm{mL}$ (Additional file 1: Figure S4B), and induced significant morphological changes of HUVECs, cells shape changed from polygonal to spindle at different concentrations less than $300 \mu \mathrm{g} / \mathrm{mL}$ (Additional file 1: Figure S4C). Different from the cellular uptake of PSC- $\mathrm{Fe}_{2} \mathrm{O}_{3}$, the bare- $\mathrm{Fe}_{2} \mathrm{O}_{3}$ was able to be engulfed by HUVECs evidenced by the increasing blue color in the cells. In further, western blot analysis showed that $\alpha$ SMA was increased remarkably and VE-cad decreased at the same time in dose-dependent manner (Additional file 1: Figure S4D). These results indicated that bare$\mathrm{Fe}_{2} \mathrm{O}_{3}$ was capable of inducing EndMT on HUVECs as well, suggesting that the induction of EndMT was closely related with the intrinsic property of NPs instead of surface modification and cellular uptake. Note, both PSC- $\mathrm{Fe}_{2} \mathrm{O}_{3}$ and bare- $\mathrm{Fe}_{2} \mathrm{O}_{3}$ were household, which should not be taken as equal ones to commercial products in application, considering that they may have 

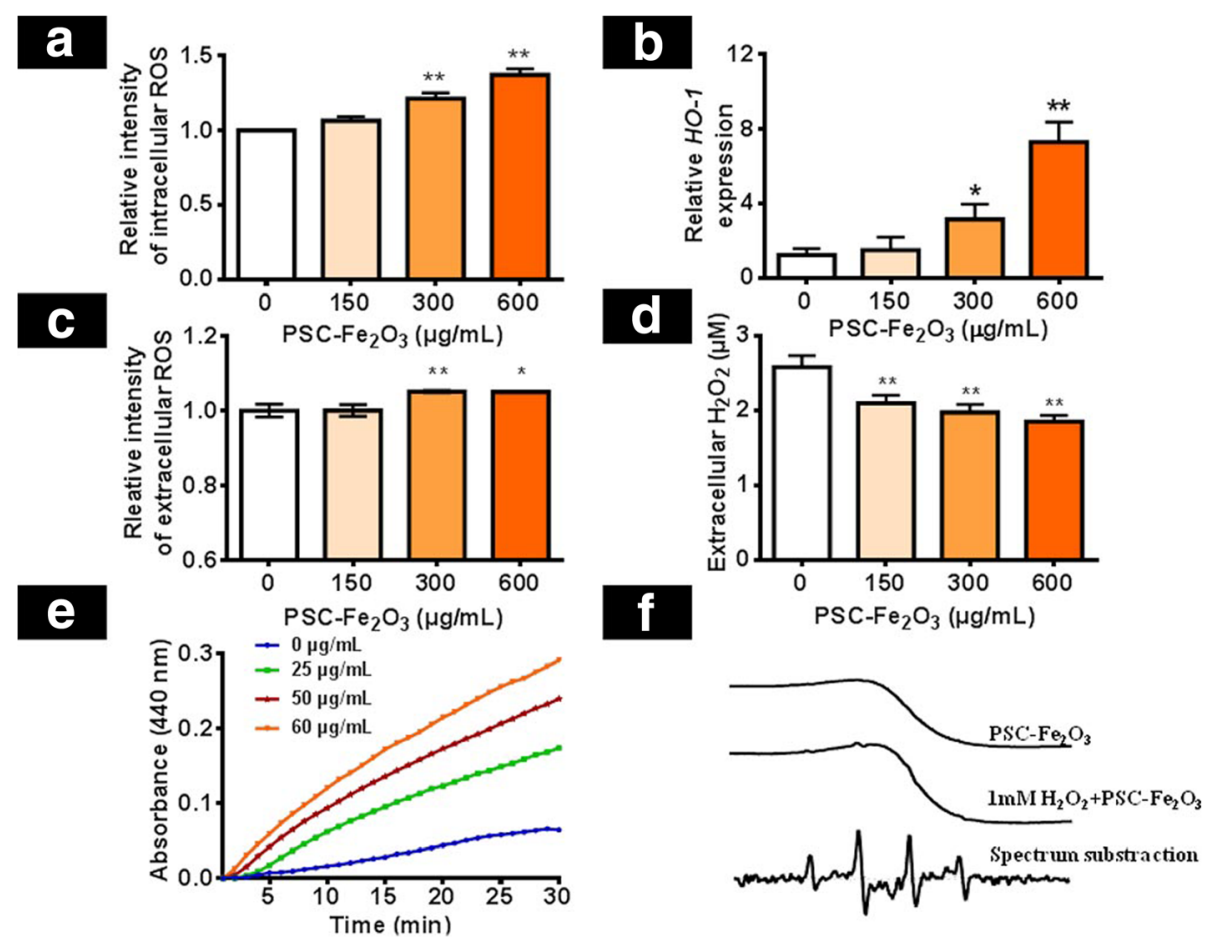

Fig. 4 PSC- $\mathrm{Fe}_{2} \mathrm{O}_{3}$ induced $\cdot \mathrm{OH}$ production by peroxidase-like activities. a Intracellular ROS of HUVEC. $\mathbf{b}$ HO-1 gene expression of HUVEC. c Extracellular ROS of HUVEC. d Extracellular $\mathrm{H}_{2} \mathrm{O}_{2}$. e PSC- $\mathrm{Fe}_{2} \mathrm{O}_{3}$ catalyzed $\mathrm{H}_{2} \mathrm{O}_{2}$ into $\cdot \mathrm{OH}$ in a concentration dependent manner. $\mathbf{f}$ The ESR spectrum of DMPO / OH adduct. Data are mean $\pm \mathrm{SD}, \mathrm{n}=3$, one-way ANOVA with Dunnett's multiple comparisons test, ${ }^{*} p<0.05,{ }^{* *} p<0.01$, significant compared to control

different physicochemical properties. It was known that EndMT is a subtype of epithelial-mesenchymal transition (EMT). Several nanoparticles or nanostructures have been demonstrated to be able to induce EMT with epithelial cell in the pulmonary system or cancer cell, such as carbon nanotube [35-38], cerium oxide [39], titanium dioxide $\left(\mathrm{TiO}_{2}\right)$ [40], silica $\left(\mathrm{SiO}_{2}\right)$ [41], silver NPs [42], which is supportive to our observations on PSC- $\mathrm{Fe}_{2} \mathrm{O}_{3}$-induced EndMT. These insights about PSC$\mathrm{Fe}_{2} \mathrm{O}_{3}$-induced EndMT can also provide a new view to evaluate the potential health risk of this nanoparticle in further applications.

IONPs are able to induce the production of intracellular ROS because they are internalized by cells and located in the lysosomes where the microenvironment is acidic [43]. Due to the surface modification, $\mathrm{PSC}-\mathrm{Fe}_{2} \mathrm{O}_{3}$ were not engulfed by HUVECs, instead, they mainly adhered to the cell membrane or stayed in the intercellular space. Nevertheless, $\mathrm{PSC}-\mathrm{Fe}_{2} \mathrm{O}_{3}$ were still capable of upregulating the level of intracellular ROS by catalyzing extracellular $\mathrm{H}_{2} \mathrm{O}_{2}$ into $\cdot \mathrm{OH}$ that further induced oxidative stress of the cells and affected intracellular environment. Therefore we suggested that the intrinsic peroxidase-like activity of $\mathrm{PSC}-\mathrm{Fe}_{2} \mathrm{O}_{3}$ brought out the EndMT effect. According to the mechanism, it was reasonable to consider that ROS scavengers could reverse the effect, which was validated by this study in vitro and in vivo. It was also important and encouraging to see that the supplementary of mannitol or AA could reduce the degree of EndMT, which implied that the combination of antioxidants with PSC- $\mathrm{Fe}_{2} \mathrm{O}_{3}$ was a promising way of prevention the risk of EndMT related toxicology for the preand clinical application with PSC- $\mathrm{Fe}_{2} \mathrm{O}_{3}$. Moreover, it was noticed that iron oxide nanoparticles could reduce the adherens conjugation between HUVECs and led to endothelial leakiness through increasing the production of ROS [21], which might be one of the potential mechanisms that trigger the occurrence of EndMT mediated by PSC- $\mathrm{Fe}_{2} \mathrm{O}_{3}$.

\section{Conclusion}

The peroxidase-like activity of $\mathrm{PSC}-\mathrm{Fe}_{2} \mathrm{O}_{3}$ resulted in the up-regulation of intracellular ROS though they were mainly stay in the culture medium and intercellular space, which induced EndMT on HUVECs with the decreased level of CD31 and VE-cadherin, and increased expression of $\alpha$-SMA and FSP. ROS scavenger mannitol or AA could rescue the EndMT induced by $\mathrm{PSC}-\mathrm{Fe}_{2} \mathrm{O}_{3}$ in vitro and in vivo. These results provided a new insight into the potential toxicity of $\mathrm{PSC}-\mathrm{Fe}_{2} \mathrm{O}_{3}$ on vascular endothelial cells and demonstrated ROS scavenge was 


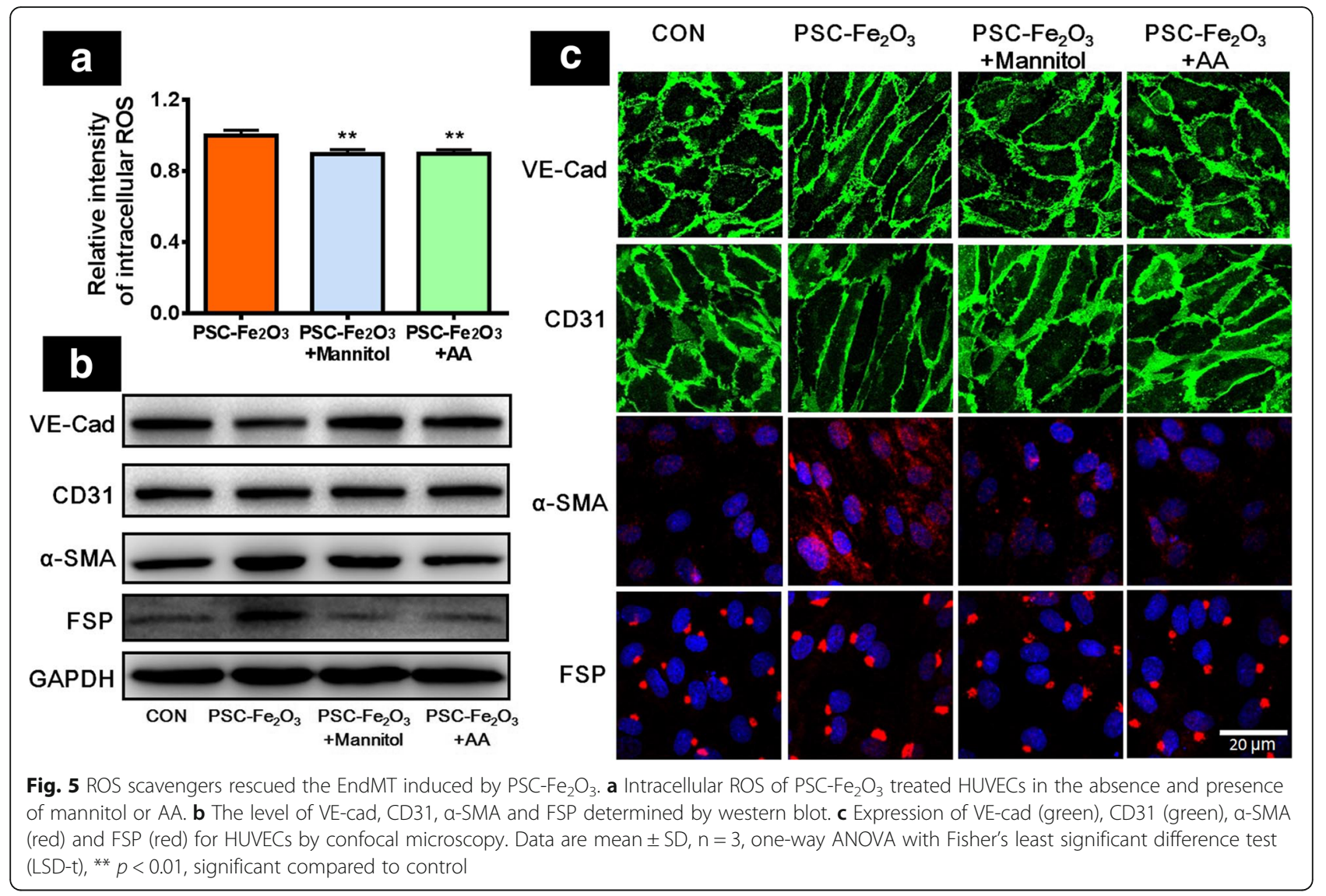

an effective strategy to reverse the process and reduce the potential toxicity.

\section{Methods}

\section{PSC-Fe2O3 synthesis and characterization}

The polydextrose sorbitol carboxymethyl ether (PSC) coated $\gamma-\mathrm{Fe}_{2} \mathrm{O}_{3}$ nanoparticles (PSC- $\mathrm{Fe}_{2} \mathrm{O}_{3}$ ) were synthetized by alternating-current magnetic field inducing method [44]. Bare $\mathrm{Fe}_{2} \mathrm{O}_{3}$ nanoparticles were prepared similar to PSC- $\mathrm{Fe}_{2} \mathrm{O}_{3}$ in the absent of PSC. The morphology of $\mathrm{Fe}_{2} \mathrm{O}_{3}$ was observed by transmission electron microscope (TEM-1400plus, JEOL). The hydrodynamic diameters and Zeta potential of PSC-Fe2O3 were detected by a Zetasizer Nano ZS90 analyzer (Malvern). Each measurement was repeated four times.

\section{Cell culture}

Human umbilical vein endothelial cells (HUVECs, \#8000), endothelial cell medium (ECM, \#1001), fetal bovine serum (FBS, \#0025), penicillin/streptomycin solution $(\mathrm{P} / \mathrm{S}, \# 0503)$, endothelial cell growth supplement (ECGS,\#1052) and Poly-L-Lysine (PLL, \#0403) were all purchased from ScienCell Research Laboratories (San Diego, CA). HUVECs were grown on PLL coated culture plate in ECM supplemented with 5\% FBS, $1 \% \mathrm{P} / \mathrm{S}$ and $1 \%$ ECGS.

\section{Cell viability assay}

The viability of HUVECs incubated with $\mathrm{Fe} 2 \mathrm{O} 3$ was analyzed using a cell count kit (CCK-8, Dojindo). The $\mathrm{Fe} 2 \mathrm{O} 3$ was diluted in fresh medium to yield a final iron concentration that ranged from 0 to $600 \mu \mathrm{g} / \mathrm{mL}$. After $24 \mathrm{~h}$ or $48 \mathrm{~h}$ incubation, the cells were rinsed twice with PBS and incubated with medium containing $10 \mu \mathrm{L}$ CCK8 reagents for $2 \mathrm{~h}$. The absorbance of the medium was measured at $450 \mathrm{~nm}$ using a microplate reader (BioTek Synergy4). All measurements were carried out in triplicate, and the cell viability was calculated with the protocol provided by the manufacture.

\section{Cell morphology assay}

HUVEC cells were exposed to 0,300 and $600 \mu \mathrm{g} / \mathrm{mL}$ PSC- $\mathrm{Fe}_{2} \mathrm{O}_{3}$. After $48 \mathrm{~h}$, the morphology of cells was observed by the microscope (Olympus IX71). The length and diameter of thirty cells in each treatment was measured by Image software, and the ratio of length to diameter (L/D) was calculated. 


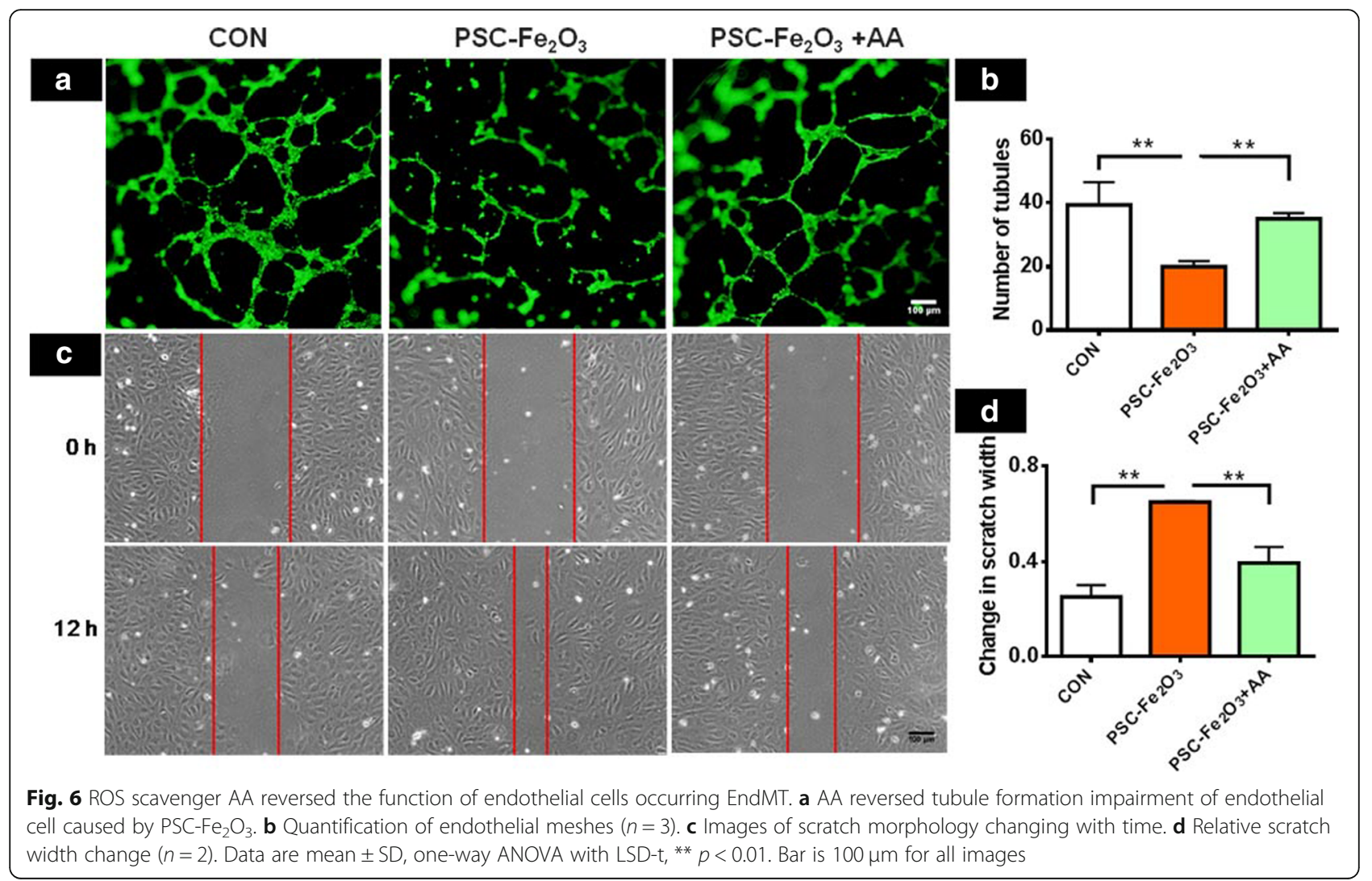

\section{Immunoblotting}

Cells were incubated with $0,150,300$ and $600 \mu \mathrm{g} / \mathrm{mL}$ $\mathrm{Fe}_{2} \mathrm{O}_{3}$ for $48 \mathrm{~h}$ at $37^{\circ} \mathrm{C}$. HUVECs were lysed in RIPA buffer and analyzed by western blot. Primary antibodies were as follows: anti-VE-cadherin (\#2500S, Cell Signaling Technology, Danvers, MA), anti-CD31 (\#3528, CST), anti- $\alpha$-smooth muscle actin (\#19245S, CST), antiFSP (\#13018, CST) and anti-GAPDH (sc-25778, Santa Cruz). Protein bands were quantified using ImageJ software. For the rescue experiment, HUVECs were cocultured by $\mathrm{Fe}_{2} \mathrm{O}_{3}$ with $0.88 \mathrm{mg} / \mathrm{mL}$ mannitol or 8.8 $\mathrm{mg} / \mathrm{mL}$ ascorbic acid (AA).

\section{Immunofluorescent staining}

Cells were treated with different concentrations of PSC$\mathrm{Fe}_{2} \mathrm{O}_{3}$ for $48 \mathrm{~h}$ and then fixed with $4 \%$ paraformaldehyde for $15 \mathrm{~min}$. After rinsing with PBS, cells were incubated with blocking solution (1\% bovine serum albumin (BSA) in PBS with $0.3 \%$ Triton) for $1 \mathrm{~h}$ at room temperature. The following primary antibodies were applied overnight at $4{ }^{\circ} \mathrm{C}$ : anti-VE-cadherin, anti-CD31, anti$\alpha$-smooth muscle actin, and anti-FSP. Cells were washed with PBS, and corresponding fluorescent secondary antibodies (CST) were applied for $1 \mathrm{~h}$ at room temperature. Nuclear staining was performed use 4', 6-diamidino-2-phenylindole (DAPI, Zhongshan Goldenbridge). Micrographs were taken by the FluoView
FV1000 confocal microscope (Olympus), and analyzed with ImageJ software. For the rescue experiment, the cells were treated with $600 \mu \mathrm{g} / \mathrm{mL}$ PSC- $\mathrm{Fe}_{2} \mathrm{O}_{3}$ and $0.88 \mathrm{mg} / \mathrm{mL}$ mannitol or $8.8 \mathrm{mg} / \mathrm{mL}$ AA. The paraffin-embedded liver, spleen, and renal sections were deparaffinized with xylene. After treatment with $3 \%$ BSA for $30 \mathrm{~min}$, sections were incubated overnight with primary CD31 and $\alpha$-SMA antibody. Slides were then washed and incubated in the dark for 50 min with corresponding alexa fluor 488 or CY3 labeled secondary antibody. Slides were then again washed in PBS and counterstained with DAPI-containing mounting medium.

\section{Tubule formation}

Cells were pretreated with $600 \mu \mathrm{g} / \mathrm{mL}$ PSC- $-\mathrm{Fe}_{2} \mathrm{O}_{3}$ in the absent or present of $50 \mathrm{mM}$ AA for $48 \mathrm{~h}$ before seeded in matrigel coated 96-well plates. Cells were allowed to attach for $8 \mathrm{~h}$, stained with Calcien AM (Molecular Probe) and photographed by the fluorescence microscope (Olympus, IX71). Numbers of tubules were quantified using ImageJ with the Angiogenesis Analyzer plugin. Data presented were from three independent experiments.

\section{Wound-healing assay}

Cells were pretreated with $600 \mu \mathrm{g} / \mathrm{mL}$ PSC- $\mathrm{Fe}_{2} \mathrm{O}_{3}$ with or without $50 \mathrm{mM} \mathrm{AA}$ for $48 \mathrm{~h}$ and then starved without 


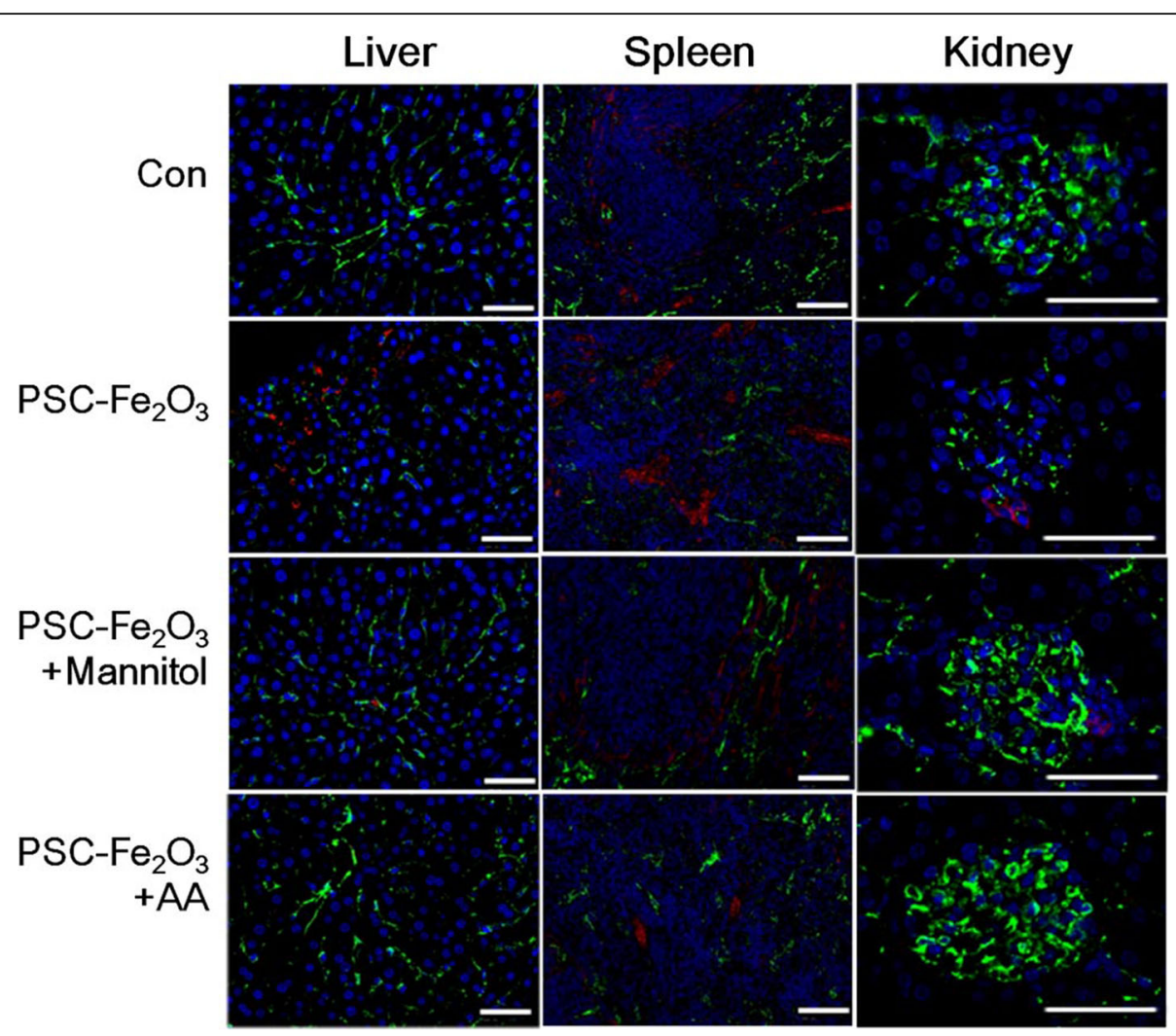

Fig. 7 Representative of liver, spleen and kidney sections stained for mesenchymal markers a-SMA (red), the endothelial markers CD31 (Green), and nuclei (blue). Bar is $50 \mu \mathrm{m}$ for all images

a

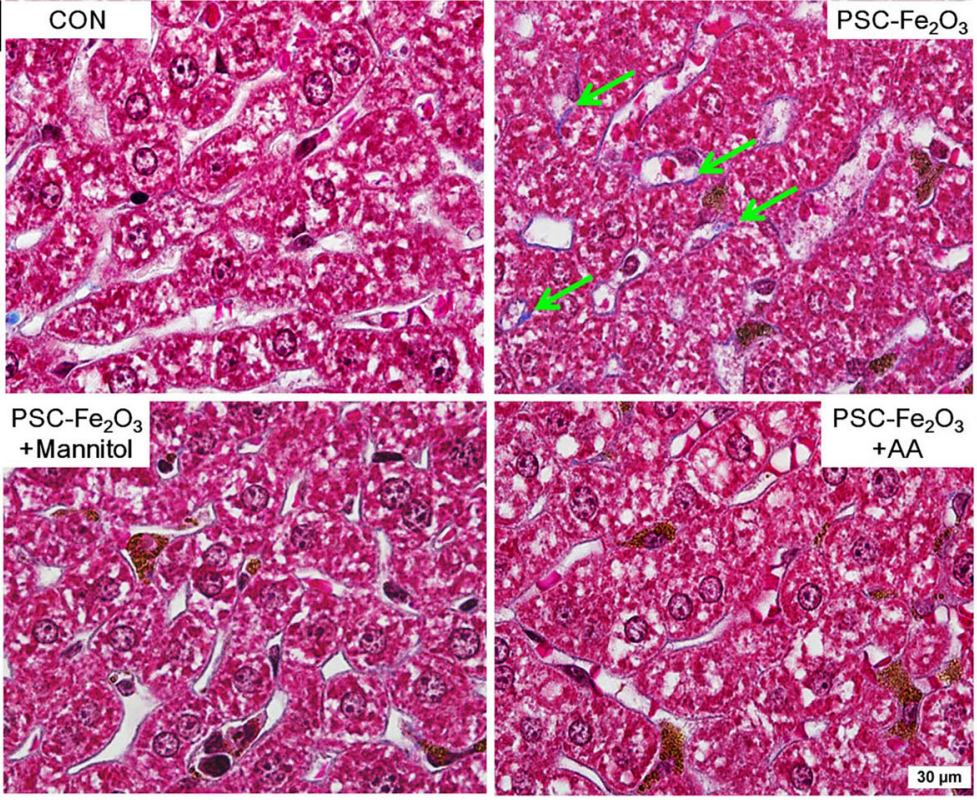

b

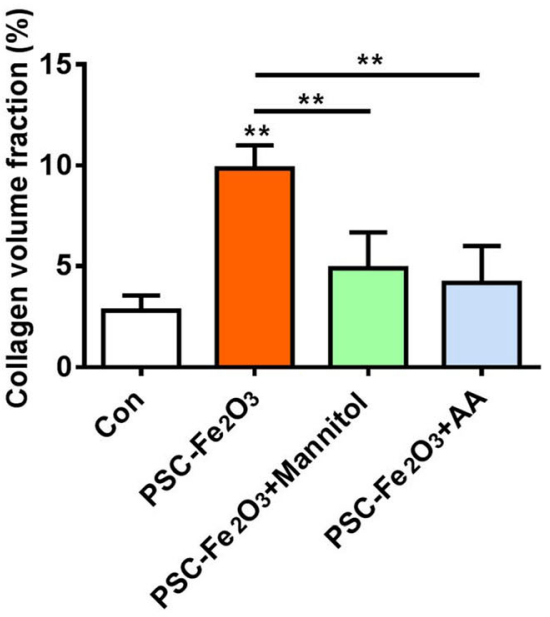

Fig. 8 a Representative images of liver sections with Masson's trichrome staining (blue color pointed by green arrows) for extracellular matrix collagen. b Quantification of collagen volume fraction. Data are mean $\pm \mathrm{SD}, n=4$, one-way ANOVA with LSD-t, ${ }^{*} p<0.05,{ }^{*} p<0.01$ 
FBS for $12 \mathrm{~h}$. Wounds were made with $200 \mu \mathrm{L}$ sterile pipette tip and washed with PBS to eliminate non adherent cells, thus a wound approximate $165 \mu \mathrm{m}$ was created. Then cells were cultured with medium with $0.5 \%$ FBS and images were acquired at 0 and $12 \mathrm{~h}$ (Olympus IX71). Movements of cells were calculated using ImageJ software. The changes of scratch width were calculated with initial wound width subtracted to that of $12 \mathrm{~h}$ and then divided by the initial one.

\section{Prussian blue staining}

Cells were treated with different concentrations of $\mathrm{Fe}_{2} \mathrm{O}_{3}$ for $48 \mathrm{~h}$. After removing the culture medium, the cells were washed with PBS for three times and fixed with $4 \%$ paraformaldehyde for $30 \mathrm{~min}$. The fixed cells were incubated with Prussian blue solution containing 5\% hydrochloric acid aqueous solution and $5 \%$ potassium ferrocyanide (II) trihydrate for $30 \mathrm{~min}$ to determine the intracellular iron followed by staining with nuclear fast red. The cells were placed on an inverted microscope for observation.

\section{Transmission electron microscopy (TEM)}

Cells were treated with $600 \mu \mathrm{g} / \mathrm{mL}$ PSC- $\mathrm{Fe}_{2} \mathrm{O}_{3}$ for $48 \mathrm{~h}$ and then detached with trypsin and fixed overnight with $2.5 \%$ glutaraldehyde at $4{ }^{\circ} \mathrm{C}$. The samples were then postfixed in Osmium (VIII) tetroxide $\left(\mathrm{OsO}_{4}\right)$, dehydrated in ethanol, and embedded in Epon (Fluka). Sections were cut with an ultra-microtome and placed on copper grids for observation (TEM-1400 plus, JEOL).

\section{Iron content measurements}

Cells were treated with $\mathrm{PSC}-\mathrm{Fe}_{2} \mathrm{O}_{3}$ for $48 \mathrm{~h}$. There are two different procedures to deal with HUVECs before detecting the iron content in cells. Procedure I: the cells were washed with PBS and lysed by $100 \mu \mathrm{L}$ RIPA. Procedure II: the cells washed with PBS were detached from the plates with trypsin and collected by centrifugation, and then washed with PBS and lysed by $100 \mu \mathrm{L}$ RIPA. The amount of iron was quantified with phenanthroline spectrophotometric method [45]. The iron content in the culture medium was determined with the same method. Standard calibration of iron amount and absorbance at $510 \mathrm{~nm}$ was built by using series concentration $(0,20,40,60,80,100 \mu \mathrm{g} / \mathrm{mL})$ of $\mathrm{FeCl}_{3}$ solution. The concentrations of iron in the lysates and medium were calculated from the standard curve. Data presented were from three independent experiments performed in triplicate.

Intracellular reactive oxygen species (ROS) measurement The intracellular ROS level was measured using the probe $2^{\prime}, 7^{\prime}$-dichlorodihydrofluorescein diacetate (DCFH-DA, Sigma-Aldrich). HUVECs were treated with various concentration of $\mathrm{PSC}-\mathrm{Fe}_{2} \mathrm{O}_{3}$ for $24 \mathrm{~h}$ and the culture supernatant was collected. The cells were then washed with PBS for three times. Cells were incubated with $10 \mu \mathrm{M}$ DCFH-DA for $30 \mathrm{~min}$ and then digested and collected. The fluorescence intensity was detected by flow cytometer (BD Accuri C6). For the rescue experiment, the cells were treated by PSC-Fe $\mathrm{O}_{3}$ with $0.88 \mathrm{mg} / \mathrm{mL}$ mannitol or $8.8 \mathrm{mg} / \mathrm{mL}$ AA. Data presented were from three independent experiments performed in triplicate.

\section{Extracellular $\mathrm{H}_{2} \mathrm{O}_{2}$ and ROS measurement}

The extracellular $\mathrm{H}_{2} \mathrm{O}_{2}$ and $\mathrm{ROS}$ level was measured using the above collected supernatants. In order to avoid interference from $\mathrm{PSC}-\mathrm{Fe}_{2} \mathrm{O}_{3}$, ultrafiltration centrifugal filter $\left(10 \mathrm{~K}\right.$, Amicon $\left.^{\circ}\right)$ was used to separate $\mathrm{PSC}-\mathrm{Fe}_{2} \mathrm{O}_{3}$ from supernatants. Centrifugal filter was performed following the manufacturer's recommendations. In short, the supernatants were added to the device, followed by centrifugation. Then, the solution in the filter collection tube was collected.

The $\mathrm{H}_{2} \mathrm{O}_{2}$ concentration in the filtered solution was detected by hydrogen peroxide assay Kit (Beyotime Biotechnology). Standard calibration of $\mathrm{H}_{2} \mathrm{O}_{2}$ was built by using series concentration $(1,2,5,10,20 \mu \mathrm{M})$ of $\mathrm{H}_{2} \mathrm{O}_{2}$ solution (Beijing Chemical Works) with absorbance at $560 \mathrm{~nm}$. The concentration of $\mathrm{H}_{2} \mathrm{O}_{2}$ in the filtered solution was calculated with the standard curve. Data from three independent experiments were presented.

To explore the effect of PSC- $\mathrm{Fe}_{2} \mathrm{O}_{3}$ on extracellular ROS production, we used a modified assay with DCFH-DA probe [46]. DCFH-DA in DMSO was hydrolyzed in $\mathrm{NaOH}$ aqueous solution for $30 \mathrm{~min}$ to yield DCFH intermediate. The obtained DCFH solution was neutralized with $\mathrm{NaH}_{2} \mathrm{PO}_{4}$ and shielded from light. The obtained filtered supernatants were mixed with DCFH solution. After 30-min incubation, the fluorescence was detected (BioTek Synergy4) and the excitation and emission wavelengths were set at 488 and $525 \mathrm{~nm}$, respectively.

\section{qPCR}

Cells were incubated with $0,150,300$ and $600 \mu \mathrm{g} / \mathrm{mL}$ PSC- $\mathrm{Fe}_{2} \mathrm{O}_{3}$ for $24 \mathrm{~h}$ at $37^{\circ} \mathrm{C}$. The total RNA of the cells was extracted by using trizol (MKCB2851V, Sigma) with one-step extraction. Total RNA was transcribed using the cDNA synthesis kit (\#RR036A, TaKaRa). Quantitative real-time-PCR (qPCR) was performed using the real-time PCR system (Bio-Rad) and TB Green fluorescein mix (\#RR420A, TaKaRa). Data were normalized based on GAPDH expression as housekeeping gene. All primers were synthesized from TSINGKE Biological Technology and shown in Table 1. 
Table 1 Sequences information of the gene primers

\begin{tabular}{lll}
\hline & Forward & Reverse \\
\hline HO-1 & AAGACTGCGTTCCTGCTCAAC & AAAGCCCTACAGCAACTGTCG \\
GAPDH & GTCAAGCTCATTCCTGGT & CCAGGGTTTCTTACTCCTTG \\
\hline
\end{tabular}

\section{In vitro peroxidase-like activity assay}

The peroxidase-like activity of $\mathrm{PSC}-\mathrm{Fe}_{2} \mathrm{O}_{3}$ was evaluated in deionized water with the catalytic oxidation of $\mathrm{o}$ phenylenediamine (OPD). The peroxidase-like activities of different concentrations $(0,25,50,60 \mu \mathrm{g} / \mathrm{mL})$ PSC$\mathrm{Fe}_{2} \mathrm{O}_{3}$ were employed with $45 \mu \mathrm{g} / \mathrm{mL}$ OPD and $370 \mathrm{mM}$ $\mathrm{H}_{2} \mathrm{O}_{2}$. The progress was monitored with UV-vis-NIR spectrophotometer (PerkinElmer Lambda 950) with 1min intervals at $440 \mathrm{~nm}$. All operations were done at room temperature and in the dark.

\section{Electron spin resonance (ESR)}

Hydroxyl radicals $(. \mathrm{OH})$ can be detected by ESR with the help of the spin trap 5,5-Dimethyl-1-pyrroline $\mathrm{N}$ oxide (DMPO, Dojindo). The ESR measurements were carried out using a Magnettech ESR spectrometer (MS5000) at ambient temperature. $50 \mu \mathrm{L}$ aliquots of control or sample solutions were taken in quartz capillary tubes. Other settings were as follows: $2 \mathrm{G}$ field modulation, $100 \mathrm{G}$ scan range, and $10 \mathrm{~mW}$ microwave power.

\section{Animal experiments}

Animal experiments were carried out in accordance with a protocol that was approved by the Institutional Animal Care and Use committee (Institute of Basic Medical Sciences, Chinese Academy of Medical Sciences, and Peking Union Medical College). Female Balb/c mice (average weight $20 \mathrm{~g}$ ) were maintained at the institutional experimental animal center under specific pathogen-free conditions. The mice were fed with sterilized food and autoclaved tap water.

Mice were divided into four groups, and each group consisted of three mice. Mice were intravenous injection of PSC- $\mathrm{Fe}_{2} \mathrm{O}_{3}$ or in combination with mannitol or oral administration AA as the following table showed (Table 2).

The mice were treated once a day for 7 days and then sacrificed. The tissues were collected and fixed in $4 \%$

Table 2 The administration procedure of mice

\begin{tabular}{|c|c|c|}
\hline Group & $\begin{array}{l}\text { Intragastrical } \\
\text { administration }(100 \mu \mathrm{L})\end{array}$ & intravenous injection $(100 \mu \mathrm{L})$ \\
\hline Control & saline & saline \\
\hline $\mathrm{PSC}-\mathrm{Fe}_{2} \mathrm{O}_{3}$ & saline & $4 \mathrm{mg} / \mathrm{mL}$ PSC- $-\mathrm{Fe}_{2} \mathrm{O}_{3}$ \\
\hline $\begin{array}{l}\mathrm{PSC}-\mathrm{Fe}_{2} \mathrm{O}_{3}+ \\
\text { AA }\end{array}$ & $40 \mathrm{mg} / \mathrm{mL}$ AA & $4 \mathrm{mg} / \mathrm{mL}$ PSC- $-\mathrm{Fe}_{2} \mathrm{O}_{3}$ \\
\hline $\begin{array}{l}\mathrm{PSC}_{-} \mathrm{Fe}_{2} \mathrm{O}_{3}+ \\
\text { mannitol }\end{array}$ & saline & $\begin{array}{l}4 \mathrm{mg} / \mathrm{mL} \mathrm{PSC}-\mathrm{Fe}_{2} \mathrm{O}_{3}+5.87 \\
\mathrm{mg} / \mathrm{mL} \text { mannitol }\end{array}$ \\
\hline
\end{tabular}

Note: saline was $0.9 \%$ sodium chloride parformaldehyde for $24 \mathrm{~h}$ and subsequently embedded in paraffin for histopathological and immunohistochemistry analysis.

\section{Histopathological and immunohistochemistry analysis}

The paraffin-embedded tissue sections were deparaffinized with xylene. Endogenous peroxidase was blocked with $0.3 \% \mathrm{H}_{2} \mathrm{O}_{2}$ for $25 \mathrm{~min}$. After treatment with 3\% BSA for $30 \mathrm{~min}$, sections were incubated overnight with primary CD31 and $\alpha$-SMA antibody. Slides were then washed and incubated with a horse radish peroxidase-linked secondary antibody for $50 \mathrm{~min}$ at room temperature, followed by diaminobenzidine and counterstaining with Mayer's hematoxylin.

The slides were stained with Masson's trichrome for evaluation of interstitial collagen deposition. Collagen area and total tissue area were measured using ImageJ and the IHC Tool Box plugin. Collagen volume fraction (CVF) was calculated dividing collagen area by the total area. For each group, four replicates were counted and calculated.

\section{Statistical analysis}

The data are shown as mean \pm standard deviation (SD) for all treatment groups. Statistical significance was ascertained through one way ANOVA with SPSS software (SPSS17.0).

\section{Additional file}

Additional file 1: Figure S1. Representative morphology of low density of HUVECs treated with 300 and $600 \mu \mathrm{g} / \mathrm{mL}$ PSC- $\mathrm{Fe}_{2} \mathrm{O}_{3}$. Figure S2. PSC$\mathrm{Fe}_{2} \mathrm{O}_{3}$ inhibited $\mathrm{CD} 31$ protein and gene expression, which was rescued by antioxidants. (A) Three replications of CD31 immunoblots. (B)

Quantification of CD31 expression for HUVECs with different treatments. (C) Gene expression of CD31 for endothelial cell with different treatments Data are mean \pm SD, one-way ANOVA with LSD-t, ${ }^{* *} p<0.01$. Figure S3. Representative of liver sections stained for mesenchymal markers a-SMA, and the endothelial markers CD31. Figure S4. Effects of bare $\mathrm{Fe}_{2} \mathrm{O}_{3}$ nanoparticles (bare- $\mathrm{Fe}_{2} \mathrm{O}_{3}$ ) on HUVECs. (A) TEM image for bare- $\mathrm{Fe}_{2} \mathrm{O}_{3}$. (B) Cell viability of HUVECs treated with different concentrations of bare$\mathrm{Fe}_{2} \mathrm{O}_{3}$ for $24 \mathrm{~h}$ or $48 \mathrm{~h}$. (C) Representative immunoblots of VE-Cadherin and a-SMA of HUVECs treated with $0,10,50$ and $300 \mu \mathrm{g} / \mathrm{mL}$ of bare$\mathrm{Fe}_{2} \mathrm{O}_{3}$ for $48 \mathrm{~h}$. (D) Microscope observation of HUVEC cells treated with different concentrations of bare- $\mathrm{Fe}_{2} \mathrm{O}_{3}$ after Prussian blue staining. (DOCX $1010 \mathrm{~kb}$ )

\section{Abbreviations}

AA: ascorbic acid; DCFH-DA: 2', 7'-dichlorodihydrofluorescein diacetate; DMPO: 5, 5-Dimethyl-1-pyrroline N-oxide; ECs: Endothelial cell; EndMT: Endothelial-to-mesenchymal transition; ESR: Electron spin resonance; FSP: Fibroblast specific protein; HUVEC: Human umbilical vein endothelial cells; IONPs: Iron oxide nanoparticles; $\mathrm{OH}$ : Hydroxyl radicals; OPD: ophenylenediamine; $\mathrm{PSC}-\mathrm{Fe}_{2} \mathrm{O}_{3}: \mathrm{y}-\mathrm{Fe}_{2} \mathrm{O}_{3}$ nanoparticle core and polyglucose sorbitol carboxymethyether shell; ROS: Reactive oxygen species;

TEM: Transmission electron microscope; a-SMA: a-smooth muscle actin

Acknowledgements

Not applicable. 


\section{Consent of publication}

Not applicable.

\section{Authors' contributions}

TW, JM, and HYX designed experiments and made data analysis and wrote the main manuscript. LFD conducted main experiments and prepared data for Figs. BC provided the PSC- $\mathrm{Fe}_{2} \mathrm{O}_{3}$ and related data. TW, JM, DDY and AYY took part in part of the experiments. TW, JM, JL, NG and HYX discussed part sections of the manuscript. All authors reviewed the manuscript. All authors read and approved the final manuscript.

\section{Funding}

The work was supported by the National Key R\&D Program of China (2017YFA0205504), CAMS Innovation Fund for Medical Science (CIFMS 2016- I2M-3-004 and 2018-I2M-3-006), and the National Natural Science Foundation of China (31771005 and 81801771).

\section{Availability of data and materials}

The datasets used and/or analysed during the current study are available from the corresponding author on reasonable request.

\section{Ethics approval and consent to participate}

Animal experiments were carried out in accordance with a protocol that was approved by the Institutional Animal Care and Use committee (Institute of Basic Medical Sciences, Chinese Academy of Medical Sciences, and Peking Union Medical College, China). Female Balb/c mice were maintained at the institutional experimental animal center under specific pathogen-free conditions. The mice were fed with sterilized food and autoclaved tap water.

\section{Competing interests}

The authors declare that they have no competing interests.

\section{Author details}

${ }^{1}$ Institute of Basic Medical Sciences, Chinese Academy of Medical Sciences \& Peking Union Medical College, Beijing 100005, China. ${ }^{2}$ Materials Science and Devices Institute, Suzhou University of science and Technology, Suzhou 215009, China. ${ }^{3}$ State Key Laboratory of Bioelectronics, Jiangsu Key Laboratory for Biomaterials and Devices, School of Biological Science and Medical Engineering, Southeast University, Nanjing 210096, China.

\section{Received: 22 March 2019 Accepted: 7 July 2019}

\section{Published online: 12 July 2019}

\section{References}

1. Cardoso VF, Francesko A, Ribeiro C, Banobre-Lopez M, Martins P, LancerosMendez S. Advances in magnetic nanoparticles for biomedical applications. Adv Healthc Mater. 2018;7:5.

2. Hu Y, Mignani S, Majoral JP, Shen M, Shi X. Construction of iron oxide nanoparticle-based hybrid platforms for tumor imaging and therapy. Chem Soc Rev. 2018;47(5):1874-900. https://doi.org/10.1039/C7CS00657H.

3. Duan M, Shapter JG, Qi W, Yang S, Gao G. Recent progress in magnetic nanoparticles: synthesis, properties, and applications. Nanotechnology. 2018;29(45):452001. https://doi.org/10.1088/1361-6528/aadcec.

4. Valdiglesias V, Kilic G, Costa C, Fernandez-Bertolez N, Pasaro E, Teixeira JP, et al. Effects of iron oxide nanoparticles: cytotoxicity, genotoxicity, developmental toxicity, and neurotoxicity. Environ Mol Mutagen. 2015;56(2):125-48. https://doi.org/10.1002/em.21909.

5. Feliu N, Docter D, Heine M, Del Pino P, Ashraf S, Kolosnjaj-Tabi J, et al. In vivo degeneration and the fate of inorganic nanoparticles. Chem Soc Rev. 2016;45(9):2440-57. https://doi.org/10.1039/C5CS00699F.

6. Buyukhatipoglu K, Clyne AM. Superparamagnetic iron oxide nanoparticles change endothelial cell morphology and mechanics via reactive oxygen species formation. J Biomed Mater Res A. 2011;96(1):186-95. https://doi. org/10.1002/jbm.a.32972

7. Buyukhatipoglu K. Flame synthesis and in vitro biocompatibility assessment of superparamagnetic Iron oxide nanoparticles: cellular uptake, toxicity and proliferation studies. J Nanoscience Nanotechnol. 2009;9:12.

8. Ge G, Wu H, Xiong F, Zhang Y, Guo Z, Bian Z, et al. The cytotoxicity evaluation of magnetic iron oxide nanoaprticles on human aortic endothelial cells. Nanoscale Res Lett. 2013;8:215. https://doi.org/10.11 86/1556-276X-8-215.
9. Astanina K, Simon Y, Cavelius C, Petry S, Kraegeloh A, Kiemer AK. Superparamagnetic iron oxide nanoparticles impair endothelial integrity and inhibit nitric oxide production. Acta Biomater. 2014;10(11):4896-911. https://doi.org/10.1016/j.actbio.2014.07.027.

10. Kovacic JC, Mercader N, Torres M, Boehm M, Fuster V. Epithelial-tomesenchymal and endothelial-to-mesenchymal transition: from cardiovascular development to disease. Circulation. 2012;125(14):1795-808. https://doi.org/10.1161/CIRCULATIONAHA.111.040352.

11. Dufton NP, Peghaire CR, Osuna-Almagro L, Raimondi C, Kalna V, Chuahan A, et al. Dynamic regulation of canonical TGFbeta signalling by endothelial transcription factor ERG protects from liver fibrogenesis. Nat Commun. 2017;8:895.

12. Ribera J, Pauta M, Melgar-Lesmes P, Cordoba B, Bosch A, Calvo M, et al. A small population of liver endothelial cells undergoes endothelial-tomesenchymal transition in response to chronic liver injury. Am J Physiol Gastrointest Liver Physiol. 2017;313(5):G492-504. https://doi.org/10.1152/ ajpgi.00428.2016.

13. Jourde-Chiche N, Fakhouri F, Dou L, Bellien J, Burtey S, Frimat M, et al. Endothelium structure and function in kidney health and disease. Nat Rev Nephrol. 2019;15(2):87-108. https://doi.org/10.1038/s41581-018-0098-z.

14. Zeisberg EM, Tarnavski O, Zeisberg M, Dorfman AL, McMullen JR, Gustafsson $\mathrm{E}$, et al. Endothelial-to-mesenchymal transition contributes to cardiac fibrosis. Nat Med. 2007;13(8):952-61. https://doi.org/10.1038/nm1613.

15. Wesseling M, Sakkers TR, de Jager SCA, Pasterkamp G, Goumans MJ. The morphological and molecular mechanisms of epithelial/endothelial-tomesenchymal transition and its involvement in atherosclerosis. Vasc Pharmacol. 2018;106:1-8. https://doi.org/10.1016/j.vph.2018.02.006.

16. Shi Y, Vanhoutte PM. Macro- and microvascular endothelial dysfunction in diabetes. J Diabetes. 2017;9(5):434-49. https://doi.org/10.1111/1753-0407.12521.

17. Potenta S, Zeisberg E, Kalluri R. The role of endothelial-to-mesenchymal transition in cancer progression. Br J Cancer. 2008;99(9):1375-9. https://doi. org/10.1038/sj.bjc.6604662.

18. Dejana $\mathrm{E}$, Hirschi KK, Simons M. The molecular basis of endothelial cell plasticity. Nat Commun. 2017;8:14361.

19. Zhang H, Chang H, Wang LM, Ren KF, Martins MC, Barbosa MA, et al. Effect of polyelectrolyte film stiffness on endothelial cells during endothelial-tomesenchymal transition. Biomacromolecules. 2015;16(11):3584-93. https:// doi.org/10.1021/acs.biomac.5b01057.

20. Shoajei S, Tafazzoli-Shahdpour M, Shokrgozar MA, Haghighipour N. Alteration of human umbilical vein endothelial cell gene expression in different biomechanical environments. Cell Biol Int. 2014;38(5):577-81 . https://doi.org/10.1002/cbin.10237.

21. Apopa PL, Qian Y, Shao R, Guo NL, Schwegler-Berry D, Pacurari M, et al. Iron oxide nanoparticles induce human microvascular endothelial cell permeability through reactive oxygen species production and microtubule remodeling. Part Fibre Toxicol. 2009;6:1. https://doi.org/10.1186/1743-8977-6-1.

22. Chou CC, Chen W, Hung Y, Mou CY. Molecular elucidation of biological response to mesoporous silica nanoparticles in vitro and in vivo. ACS Appl Mater Interfaces. 2017;9(27):22235-51. https://doi.org/10.1021/acsami.7b05359.

23. Gao L, Zhuang J, Nie L, Zhang J, Zhang Y, Gu N, et al. Intrinsic peroxidaselike activity of ferromagnetic nanoparticles. Nat Nanotechnol. 2007;2(9):577-83. https://doi.org/10.1038/nnano.2007.260.

24. Jiang B, Duan D, Gao L, Zhou M, Fan K, Tang Y, et al. Standardized assays for determining the catalytic activity and kinetics of peroxidase-like nanozymes. Nat Protoc. 2018;13(7):1506-20. https://doi.org/10.1038/s41596-018-0001-1.

25. Zhao H, Joseph J, Zhang H, Karoui H, Kalyanaraman B. Synthesis and biochemical applications of a solid cyclic nitrone spin trap: a relatively superior trap fo detecting superoxide anions and glutathiyl radicals. Free Radic Biol Med. 2001;31(5):599-606. https://doi.org/10.1016/S0891-5849(01 )00619-0.

26. Suzuki T, Tada Y, Nishimura R, Kawasaki T, Sekine A, Urushibara T, et al. Endothelial-to-mesenchymal transition in lipopolysaccharide-induced acute lung injury drives a progenitor cell-like phenotype. Am J Physiol Lung Cell Mol Physiol. 2016;310(11):L1185-98. https:/doi.org/10.1152/ajplung.00074.2016.

27. Huynh DL, Zhang JJ, Chandimali N, Ghosh M, Gera M, Kim N, et al. SALL4 suppresses reactive oxygen species in pancreatic ductal adenocarcinoma phenotype via FoxM1/Prx III axis. Biochem Biophys Res Commun. 2018;503(4):2248-54. https://doi.org/10.1016/j.bbrc.2018.06.145.

28. Gao L, Liu R, Gao F, YalingWang JX, Gao X. Plasmon-Mediated Generation of Reactive Oxygen Species from Near-Infrared Light Excited Gold Nanocages for Photodynamic Therapy in Vitro. ACS Nano. 2014;8(7):7260-71. https:// doi.org/10.1021/nn502325j. 
29. Dave Rl, Shah NP. Effectiveness of ascorbic acid as an oxygen scavenger in improving viability of probiotic bacteria in yoghurts made with commercial starter cultures. Int Dairy J. 1997;7(6-7):435-43.

30. Coll-Bonfill N, Musri MM, Ivo V, Barberà JA, Tura-Ceide O. Transdifferentiation of endothelial cells to smooth muscle cells play an important role in vascular remodelling. Am J Stem Cells. 2015;4(1):13-21.

31. Patel J, Baz B, Wong HY, Lee JS, Khosrotehrani K. Accelerated endothelial to mesenchymal transition increased fibrosis via deleting notch signaling in wound vasculature. J Invest Dermatol. 2018;138(5):1166-75. https://doi.org/1 0.1016/j.jid.2017.12.004

32. Zhou Q, Wei Y. For better or worse, Iron overload by superparamagnetic Iron oxide nanoparticles as a MRI contrast agent for chronic liver diseases. Chem Res Toxicol. 2017;30(1):73-80.

33. Setyawati MI, Tay CY, Chia SL, Goh SL, Fang W, Neo MJ, et al. Titanium dioxide nanomaterials cause endothelial cell leakiness by disrupting the homophilic interaction of VE-cadherin. Nat Commun. 2013;4:1673.

34. Tee JK, Ng LY, Koh HY, Leong DT, Ho HK. Titanium Dioxide Nanoparticles Enhance Leakiness and Drug Permeability in Primary Human Hepatic Sinusoidal Endothelial Cells. Int J Mol Sci. 2018;20(1):35.

35. Polimeni M, Gulino GR, Gazzano E, Kopecka J, Marucco A, Fenoglio I, et al. Multi-walled carbon nanotubes directly induce epithelial-mesenchymal transition in human bronchial epithelial cells via the TGF-beta-mediated Akt/GSK-3beta/SNAlL-1 signalling pathway. Part Fibre Toxicol. 2016;13(1):27. https://doi.org/10.1186/s12872-019-1042-2.

36. Chang CC, Tsai ML, Huang HC, Chen CY, Dai SX. Epithelial-mesenchymal transition contributes to SWCNT-induced pulmonary fibrosis. Nanotoxicology. 2012;6(6):600-10.

37. Chen T, Nie H, Gao X, Yang J, Pu J, Chen Z, et al. Epithelial-mesenchymal transition involved in pulmonary fibrosis induced by multi-walled carbon nanotubes via TGF-beta/Smad signaling pathway. Toxicol Lett. 2014;226(2): 150-62. https://doi.org/10.1016/j.toxlet.2014.02.004.

38. Wang $P$, Wang $Y$, Nie $X$, Braini $C$, Bai R, Chen C. Multiwall carbon nanotubes directly promote fibroblast-myofibroblast and epithelial-mesenchymal transitions through the activation of the TGF-beta/Smad signaling pathway. Small. 2015;11(4):446-55. https://doi.org/10.1002/smll.201303588.

39. Ma J, Bishoff B, Mercer RR, Barger M, Schwegler-Berry D, Castranova V. Role of epithelial-mesenchymal transition (EMT) and fibroblast function in cerium oxide nanoparticles-induced lung fibrosis. Toxicol Appl Pharmacol. 2017;323: 16-25. https://doi.org/10.1016/j.taap.2017.03.015.

40. Setyawati MI, Sevencan C, Bay BH, Xie J, Zhang Y, Demokritou P, et al. NanoTiO2 Drives Epithelial-Mesenchymal Transition in Intestinal Epithelial Cancer Cells. Small. 2018;14(30):1800922. https://doi.org/10.1002/smll.201800922.

41. Yang $M$, Qian $X$, Wang $N$, Ding $Y, L i ~ H$, Zhao $Y$, et al. Inhibition of MARCO ameliorates silica-induced pulmonary fibrosis by regulating epithelialmesenchymal transition. Toxicol Lett. 2019;301:64-72. https://doi.org/10.1 016/j.toxlet.2018.10.031.

42. Choo WH, Park CH, Jung SE, Moon B, Ahn H, Ryu JS, et al. Long-term exposures to low doses of silver nanoparticles enhanced in vitro malignant cell transformation in non-tumorigenic BEAS-2B cells. Toxicol in Vitro. 2016;37:41-9. https://doi.org/10.1016/j.tiv.2016.09.003.

43. Chen Z, Yin J-J, Zhou Y-T, Zhang Y, Song L, Song M, et al. Dual enzyme-like activities of Iron oxide nanoparticles and their implication for Diminishing Cytotoxicity. ACS Nano. 2012;6(5):4001-12. https:/doi.org/10.1021/nn300291r.

44. Chen B, Li Y, Zhang X, Liu F, Liu Y, Ji M, et al. An efficient synthesis of ferumoxytol induced by alternating-current magnetic field. Materials Letters. 2016;170:93-6

45. Hao S, Meng J, Zhang Y, Liu J, Nie X, Wu F, et al. Macrophage phenotypic mechanomodulation of enhancing bone regeneration by superparamagnetic scaffold upon magnetization. Biomaterials. 2017;140:16-25. https://doi.org/10.1 016/j.biomaterials.2017.06.013.

46. Lin AH, Liu MH, Ko HK, Perng DW, Lee TS, Kou YR. Lung epithelial TRPA1 transduces the extracellular ROS into transcriptional regulation of lung inflammation induced by cigarette smoke: the role of Influxed $\mathrm{Ca}^{2+}$. Mediat Inflamm. 2015;2015:148367.

\section{Publisher's Note}

Springer Nature remains neutral with regard to jurisdictional claims in published maps and institutional affiliations.

Ready to submit your research? Choose BMC and benefit from:

- fast, convenient online submission

- thorough peer review by experienced researchers in your field

- rapid publication on acceptance

- support for research data, including large and complex data types

- gold Open Access which fosters wider collaboration and increased citations

- maximum visibility for your research: over $100 \mathrm{M}$ website views per year

At BMC, research is always in progress.

Learn more biomedcentral.com/submissions 